\title{
Education and Its Role in the Economic Development of the Country and Government Policies to be Undertaken to Increase the Quality of Education, the Case of Albania
}

\author{
Dr. Sc. Eriona Deda \\ Professor, "Ukshin Hoti” University, \\ Prizren, Kosovo \\ Prof. Asoc. Dr. Sokol Pacukaj \\ Vice Rector, “Aleksandër Moisiu” University, \\ Durrës, Albania \\ Prof. Ass. Dr. Luan Vardari \\ Professor, Faculty of Economics, \\ "Universum College", Kosovo
}

DOI: https://doi.org/10.36941/jesr-2021-0018

\section{Abstract}

Our paper focuses on education and, how the high-quality education affects welfare and economic growth in the case of Albania. The data were provided by INSTAT (Institute of Statistics, Albania) on the results of the adult education survey by gender, age group which refers to the population aged 25-64 years and, level of education, including three levels of education, elementary/primary education, secondary education, and postsecondary/higher education. Despite the fact that we provided the data in 2017, they would serve us to highlight some problems related to the quality of education in Albania, which would be important to develop different strategies to improve these problems in the coming years. Another priority of this paper is to define and recommend some government policies that would increase the quality of education, in order for us to have a better economic growth in the future. Here we have used the descriptive method, and through tables and charts we have provided a comparative analysis, based on some statistics which are expressed in percentage (\%). However, the main purpose here is to show through comparative analysis the level of participation in types of education, trainings, and cultural activities by gender, age group, and level of education, therefore showing the relationship between the quality of education and economic growth. We will also handle some of the government policies that recommend in order to increase quality of the education in the future.

Keywords: quality of education, government policies, economic growth

\section{Introduction}

Through this comparative analysis, based on some statistics which are expressed in percentage (\%) we aim to analyze the level of participation in formal, non-formal and informal education by gender, age 
groups and education levels in relation to the total number of respondents to our survey.

Formal education refers to a structured and systematic form of learning. Formal education is standardized and applied in all institutions (e.g. in schools, colleges, universities, etc..) (Eaton, 2010).

Unlike formal education, informal education lacks its structure and standards. In comparison to formal education, informal education takes place in non-instructional educational institutions and organizations through lifelong learning methods and activities, such as learning while staying at home, going to libraries, museums and getting informed through media, computer, Internet etc.. (Eaton, 2010).

Non-formal education is more structured than informal education, but unlike formal education it is not structured in a systematic way. Some examples of non-formal education are various courses in education, trainings, workshops, conferences, etc.. (Eaton, 2010).

Informal education is an important part of our paper, and through comparative analysis, based on some statistics which are expressed in percentage we will analyze the level of participation in informal education by gender, age group, and education levels, in relation to the total number of respondents to our survey.

Through this comparative analysis, which as we mentioned above is based on statistics, we will also analyze the knowledge of the respondents regarding the number of foreign languages they can speak, as well as the level of participation in various cultural events which take occur several times during the year by gender, age group, and education level several times a year. Based on this analysis we will draw conclusions and point out a series of problems related to the quality of education in Albania, by making some recommendations regarding the government policies that a country should undertake in order to increase the quality of education in the future. Furthermore, we will show why the quality of education is a key factor in increasing the economic growth of a country.

\section{Literature Review}

In terms of literature review, there are several other authors who have addressed topics similar which are similar to ours. And, here can mention the World Bank Policy Research Working Paper by Eric A. Hanushek and Ludger Wößmann (Hanushek \& Wößmann, 2007) entitled : "The Role of Education Quality in Economic Growth". In their paper they focus mainly on the role of education in economic growth and with a special focus on the quality of education. They show how developments in education are directly related to individual income and economic growth. The quality of education plays a special role, and there exists a connection between the quality of education and the quality of economic institutions. Of particular importance in this report are international comparative analyses which include comparative data regarding the quality of education in developed and developing countries, and how the high quality of education affects the economic growth in developed countries, by highlighting some problems that significantly affect the low quality of education in developing countries, and emphasizing the ineffective policies that directly affect the lower quality of education and economic growth compared to developed countries. This report pays special attention to the quality of education, by evaluating the importance of government policies in increasing the education quality in developing countries, and the connection that exists between the quality of education and economic growth based on effective comparative analyses which clearly reflect the changes in the quality of education between developed and developing countries and how these changes have affected the economic growth.

Other authors who have conducted studies on topics similar to ours are: Noah Berger and Peter Fisher (Berger \& Fisher, 2013), who made a report on: A well-educated workforce is key to state prosperity. Their report focuses mainly on the connection and correlation that exists between productivity, quality of education and economic growth, based on a comparative analysis of countries with developed economies and high productivity, and countries with less developed economies. This analysis also shows how the connection between productivity and the increasing quality of education has influenced the economic growth of countries with developed economies. In their report they 
emphasize that the best way to increase a country's productivity is to invest in education.. They also show that there is a strong correlation between the educational attainment of a country's workforce and the average wages of that country, indicating that countries with developed economies have a welleducated workforce and offer higher wages compared to countries with economies under development. They are also focused on some government policies that a country should undertake in order to establish some solid pillars for its economy, by putting an emphasis not only on the importance of investments in education, but also on innovations in the education system for the increase of the quality and performance of a country.

In their paper, they emphasize that investments in public research universities have an important role, because they lead to an increase in the degree of innovation. Inadequate investments in education weaken a country's ability for development. In their report they also show that strong education systems result in more stable economies, higher productivity, and higher wages for the country's workforce.

\section{Research Methods}

By processing the data collected by INSTAT (Institute of Statistics, Albania), through various surveys regarding the adult education by gender, age groups and education levels and through comparative analyses, based on statistics which are expressed in percentage (\%), we used the descriptive method to built charts and interpret them in relation to the level of participation in formal, non-formal and informal education, as well as in relation to the level of participation in various methods of informal education, and in different cultural activities by gender, age groups and education levels.

\subsection{The purpose of the paper}

The main purpose of our paper is to show through a comparative analysis, based on statistics which are expressed in \% (percentage) the level of participation of the respondents in formal, non-formal and informal education, as well as the level of participation in methods of informal education and cultural activities within 2017 by gender, age groups and education level.

Another purpose of this paper is to recommend some government policies that would increase the quality of education, in order for the country to have a better economic growth in the future.

\subsection{The research question}

Our paper focuses on two research questions:

1. What was the level of participation of respondents based on comparative analysis expressed in (\%) by gender, age groups and education level in formal, non-formal and informal education, as well as the level of participation in methods of informal education and cultural activities within 2017.

2. Which are some of the government policies regarding the improvement of education quality in the future in order to have a better economic growth.

\subsection{Data and choise}

The data regarding surveys on adult education for the year 2017 by gender, age group and education level were provided by INSTAT (Institute of Statistics, Albania). Through the descriptive method and the comparative analysis, based on statistics which are expressed in (\%) we have drawn up an analysis on the level of participation of the respondents in formal, non-formal and informal education, as well as the level of participation in methods of informal education and cultural activities within 2017. Through this analysis we have drawn conclusions by reflecting on some problems of the quality of education in Albania and suggesting some government policies that a country should undertake in 
order to increase the quality of education.

\section{Analysis of the Result}

The level of participation in education and training by gender, age groups and education level attained in 2017

Table 1. The level of participation in education and training by gender, age groups and education level attained, in 1000 surveys conducted in 2017.

\begin{tabular}{|l|c|c|c|}
\hline The level of participation in education and training \\
\hline & Total (per 10oo) & $\begin{array}{c}\text { Participation in formal or } \\
\text { non-formal education (\%) }\end{array}$ & $\begin{array}{c}\text { Participation in } \\
\text { informal learning (\%) }\end{array}$ \\
\hline Total & 1501.4 & 9.2 & 67.8 \\
\hline Male & 756.7 & 8.8 & 69.4 \\
\hline Female & 744.7 & 9.5 & 66.1 \\
\hline $\mathbf{2 5 - 3 4}$ & 419.9 & 17.3 & 74.0 \\
\hline $\mathbf{3 5 - 4 4}$ & 330.3 & 8.6 & 69.7 \\
\hline $\mathbf{4 5 - 5 4}$ & 385.6 & 6.1 & 64.8 \\
\hline $\mathbf{5 5}-\mathbf{6 4}$ & 365.6 & 3.5 & 62.0 \\
\hline Low education & 706.1 & 2.0 & 57.8 \\
\hline Secondary education & 520.7 & 7.0 & 71.4 \\
\hline Higher education & 270.6 & 32.3 & 87.3 \\
\hline
\end{tabular}

Source: INSTAT, 2017

Table 1. Indicates the level of participation in formal, non-formal and informal education by gender, age group and educational level. In terms of the level of participation in formal, non-formal and informal education, the participation of both genders has been higher in informal education compared to formal and non-formal education.

From the table we see that by gender, men have participated more than women in informal education, men make up $69.4 \%$ for 1000 surveys conducted in total, exactly $3.3 \%$ more than women, whereas women make up $66.1 \%$ in informal education for 1000 surveys conducted in total.

Regarding participation in formal and non-formal education, men made up $8.8 \%$ in formal and non-formal education, whereas women made up $9.5 \%$ in formal and non-formal education or $0.7 \%$ more than men for 1000 surveys conducted in total.

Regarding the age groups, we can say that for all age groups surveyed the participation in informal education has been higher than the participation in formal and non-formal education for 1000 surveys conducted in total. The age group from 25 to 34 has the highest participation in informal, formal and non-formal education compared to all other age groups. Regarding the age group $25-34,74 \%$ of this age group participates in informal education whereas $17.3 \%$ of this age group participates in formal and non-formal education. Participation in informal education of the age group $25-34$ is $56.7 \%$ higher than participation in formal and non-formal education.

Regarding the education level, for 1000 surveys conducted, the highest participation is provided by higher education. Participation in informal education was provided by the level of higher education and was $87.3 \%$ or $55 \%$ higher than participation in formal and non-formal education. 


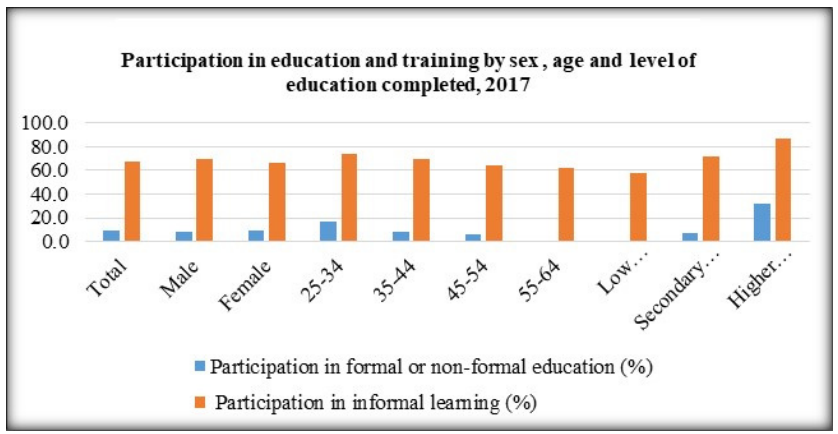

Chart 1. The level of participation in education and training by gender, age groups and education level attained.

\section{Source : Authors}

The chart shows the level of participation in education and training by gender, age groups and education level attained. We see that participation in informal education by gender, age group and education level attained has been higher than participation in formal and non-formal education.

With regards to gender, men have a higher participation in informal education compared to women. Men participated in informal education $69.4 \%$ or $3.3 \%$ more than women. In terms of formal and non-formal education, women participated in $9.5 \%$ of formal and non-formal education or $0.7 \%$ more than men.

With regards to age groups, the age group 25-34 has participated more in informal education compared to formal and non-formal education, to be more precise this age group has participated $74 \%$ in informal education or $56.7 \%$ more compared to formal education.

With regards to education level, the highest participation from 1000 surveys conducted is in informal education and in the level of higher education. Regarding the level of higher education for 1000 surveys conducted in total, $87.3 \%$ or $55 \%$ more participated in informal education compared to formal and non-formal education.

Table 2. Informal learning by gender, age groups, level of education and by methods of informal learning.

\begin{tabular}{|l|c|c|c|c|c|c|}
\hline \multicolumn{7}{|c|}{ Informal learning } \\
\hline & Family/friends & Materials & Computer & Media & Museums & Libraries \\
\hline Total & $\mathbf{5 5 3 , 7 0 2}$ & $\mathbf{3 6 4 , 8 8 4}$ & $\mathbf{5 4 7 , 7 7 1}$ & $\mathbf{8 7 2 , 2 3 0}$ & $\mathbf{2 1 1 , 4 2 5}$ & $\mathbf{1 5 1 , 3 5 6}$ \\
\hline Male & 303,701 & 177,905 & $\mathbf{2 8 4 , 6 4 9}$ & 443,680 & 113,477 & 65,404 \\
\hline Female & 250,001 & 186,979 & 263,122 & 428,550 & 97,948 & 85,951 \\
\hline $25-34$ & 180,156 & 150,296 & 235,094 & 251,101 & 79,724 & 67,739 \\
\hline $35-44$ & 131,025 & 82,438 & 129,718 & 202,510 & 49,155 & 30,896 \\
\hline $45-54$ & 132,948 & 77,861 & 111,362 & 216,747 & 50,486 & 30,043 \\
\hline $55-64$ & 109,573 & 54,289 & 71,597 & 201,872 & 32,060 & 22,678 \\
\hline Low education & 213,570 & 60,702 & 126,708 & 365,146 & 41,123 & 16,724 \\
\hline Secondary education & 184,596 & 126,369 & 201,919 & 326,745 & 69,079 & 32,692 \\
\hline Higher education & 154,151 & 176,188 & 217,760 & 178,714 & 99,839 & 100,555 \\
\hline
\end{tabular}

Source: INSTAT, 2017

Table 2, shows the methods of informal learning by gender, age groups, and level of education attained. 
With regards to gender, based on the total number of surveys conducted, men are more focused on informal learning compared to women. Men are more focused on informal learning through these informal learning methods: $55 \%$ of the total number of respondents are focused on the method of learning through family and friends. $54 \%$ through the method of informal learning from museums. $52 \%$ through the method of learning and getting informed from computers, and $51 \%$ of the total number of men surveyed are focused on the method of informal learning by media.

With regards to the method of learning and getting informed from libraries, men are less focused, more precisely they make up $43 \%$ of the total number of respondents.

Whereas, women are more focused on informal learning through these methods: $57 \%$ of women surveyed focused on informal learning through the method of learning and getting informed from libraries. 51\% through the method of learning and getting informed from materials. With regards to the method of learning through family and friends, women are less focused, more precisely they make up $45 \%$ of the total number of respondents.

With regards to age groups, we can say that based on the total number of surveys conducted, the age group 25-34 is more focused on informal learning compared to other age groups. Informal learning methods where the age group 25-34 is more focused are: Through the method of informal learning from libraries $45 \%$, the method of informal learning from the computer $43 \%$, and through the method of informal learning from materials $41 \%$.

The age group 25-34 is less focused on informal learning through the method of information through media $29 \%$, and through the method of learning from family and friends $33 \%$.

With regards to education level, we can say that based on the total number of conducted surveys, respondents belonging to the level of higher education are more focused on informal education compared to respondents belonging to the level of secondary education or lower education. Respondents with higher education level are more focused on the method of informal learning through libraries $66 \%$ followed by the method of informal learning through materials and participation in museums respectively $48 \%$ and $47 \%$. Respondents with higher education are less focused on informal learning methods through the media $20 \%$ and through the method of learning from family and friends $28 \%$.

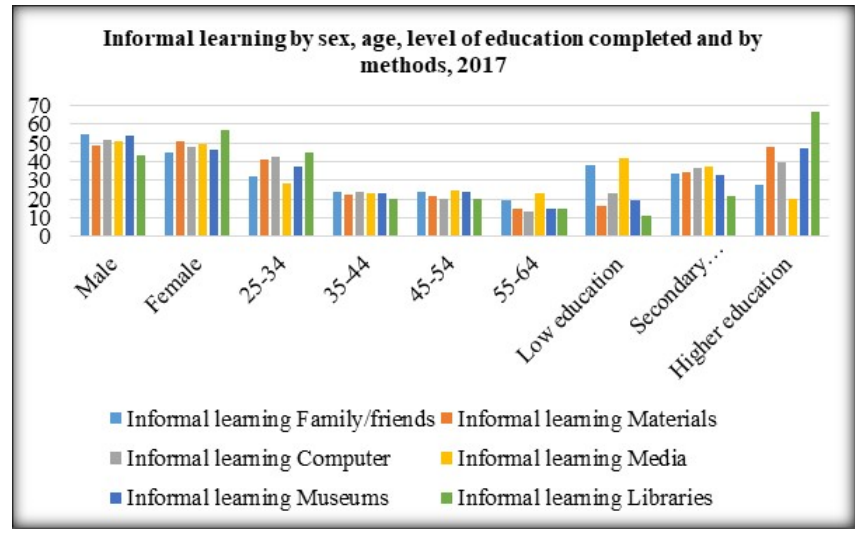

Chart 2. Informal learning by gender, age groups, level of education attained and by methods of informal learning.

Source: Authors

Chart 2, shows which methods of informal learning are the respondents more focused on by gender, age group, and education level.

With regards to gender, both genders are focused on informal learning methods but men have a higher participation in informal learning methods compared to women. The method of informal 
learning where men are more focused is: Informal learning through family and friends, and $55 \%$ of the total number of men surveyed are focused on this method of informal learning. Whereas, women are more focused on the method of informal learning from libraries, exactly $57 \%$ of the total number of women surveyed are focused on this method.

Regarding age groups, the age group 25-34 is more focused on informal learning compared to other age groups. The informal learning method where the age group 25-34 is more focused is: Regarding the informal learning method through libraries, $45 \%$ of the respondents are focused on this method.

Regarding the level of education we can say that respondents with higher education level are more focused on informal education compared to other levels of education, and exactly the method where they are more focused is the method of informal learning through libraries which has a higher value compared to all other methods of informal learning $66 \%$.

Table 3. Foreign languages by gender, age, level of education and number of foreign languages.

\begin{tabular}{|c|c|c|c|c|}
\hline \multicolumn{5}{|c|}{ Foreign languages knowledge } \\
\hline & $\begin{array}{l}\text { No foreign } \\
\text { languages }\end{array}$ & $\begin{array}{c}\text { One foreign } \\
\text { language }\end{array}$ & $\begin{array}{c}\text { Two foreign } \\
\text { languages }\end{array}$ & $\begin{array}{c}\text { Three or more } \\
\text { foreign languages }\end{array}$ \\
\hline Total & 896,674 & 388,030 & 163,148 & 47,972 \\
\hline Male & 416,409 & 229,429 & 84,045 & 24,755 \\
\hline Female & 480,265 & 158,602 & 79,103 & 23,217 \\
\hline $25-34$ & 169,747 & 135,097 & 79,868 & 32,258 \\
\hline $35-44$ & 183,418 & 93,888 & 43,304 & 9,260 \\
\hline $45-54$ & 264,911 & 90,267 & 25,509 & \\
\hline $55-64$ & 278,598 & 68,778 & 14,467 & \\
\hline Low education & 564,256 & 118,578 & 17,557 & \\
\hline Secondary education & 294,567 & 164,916 & 48,816 & 11,420 \\
\hline Higher education & 35,540 & 102,796 & 96,775 & 34,315 \\
\hline
\end{tabular}

Source: INSTAT, 2017

Table 3 shows the knowledge on the number of foreign languages spoken by respondents by gender, age and level of education.

Regarding the number of foreign languages spoken by respondents, according to gender $46 \%$ of the total number of men surveyed do not speak any foreign languages. Whereas $59 \%$ of the total number of men respondents speak a foreign language, which is precisely the largest \% compared to other options related to the number of foreign languages spoken by men respondents. $52 \%$ of the total number of men surveyed speak two foreign languages. Also,

$52 \%$ of the total number of men surveyed speak three or more foreign languages.

Whereas, with regards to women, $48 \%$ of the total number of women respondents speak two , three or more foreign languages, which is precisely the largest \% compared to other options related to the number of foreign languages spoken by women respondents.

With regards to age groups, $49 \%$ of the total number of the surveyed age group 25-34 speak one to two foreign languages. Whereas $67 \%$ of the total number of the surveyed age group 25-34 speak three or more foreign languages, which is the largest \% compared to all other age groups under study, as well as compared to the other options in relation to the number of foreign languages spoken by respondents aged 25-34.

Referring to the level of education, we can say that $59 \%$ of the total number of respondents who have a level of higher education speak two foreign languages and $72 \%$ of the total number of respondents who have a level of higher education speak three or more foreign languages, by making up the highest \% compared to other levels of education, lower education and secondary education, as 
well as the highest \% compared to other options in terms of the number of foreign languages that the respondents speak in relation to the level of education.

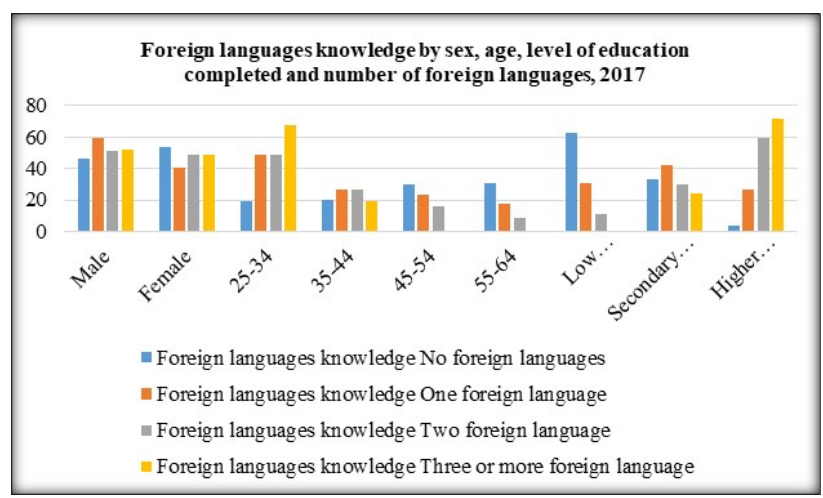

Chart 3. Foreign languages by gender, age, level of education and number of foreign languages.

Source: Authors

From chart 3 we can see the knowledge that respondents possess on foreign languages, by gender, age, and level of education.

With regards to gender, $59 \%$ of the total number of men surveyed, speak one foreign language.

Whereas, $48 \%$ of the total number of women surveyed speak two, three or more foreign languages. Both genders make up a higher \% compared to other options regarding the number of foreign languages spoken by women and men respondents.

In terms of age groups, we can say that $67 \%$ of the total number of respondents in the age group 25-34, speak three or more foreign languages.

Regarding the level of education, we can say that $72 \%$ of the total number of respondents who have a level of higher education speak three or more foreign languages, by making up the highest \% compared to other options regarding the number of foreign languages spoken by respondents in relation to their level of education.

Table 4. Shows participation in cultural events by gender, age groups, level of education and type of cultural events for 2017.

\begin{tabular}{|c|c|c|c|c|c|c|c|c|c|c|c|c|}
\hline & \multicolumn{3}{|c|}{ Live performance } & \multicolumn{3}{|c|}{ Cinema } & \multicolumn{3}{|c|}{ Cultural sites } & \multicolumn{3}{|c|}{ Live sport events } \\
\hline & $\begin{array}{c}1 \text { to } 6 \\
\text { times }\end{array}$ & $\begin{array}{l}\text { More } \\
\text { than } 6 \\
\text { times }\end{array}$ & Never & $\begin{array}{l}1 \text { to } 6 \\
\text { times }\end{array}$ & $\begin{array}{c}\text { More } \\
\text { than } 6 \\
\text { times }\end{array}$ & Never & $\begin{array}{c}1 \text { to } 6 \\
\text { times }\end{array}$ & $\begin{array}{c}\text { More } \\
\text { than } 6 \\
\text { times }\end{array}$ & Never & $\begin{array}{l}1 \text { to } 6 \\
\text { times }\end{array}$ & $\begin{array}{c}\text { More } \\
\text { than } 6 \\
\text { times }\end{array}$ & Never \\
\hline Total & 292,588 & 57,862 & $1,147,490$ & 236,967 & 61,748 & $1,199,309$ & 449,821 & 68,301 & 977,250 & 321,058 & 155,788 & $1,020,908$ \\
\hline Male & 138,850 & 28,993 & 586,838 & 127,179 & 31,761 & 595,399 & 242,616 & 32,180 & 477,862 & 245,499 & 132,175 & 378,304 \\
\hline Female & 153,738 & 28,869 & 560,652 & 109,788 & 29,987 & 603,910 & 207,205 & 36,122 & 499,388 & 75,559 & 23,613 & 642,604 \\
\hline $25-34$ & 116,064 & 23,917 & 278,961 & 102,359 & 37,305 & 279,277 & 163,677 & 29,361 & 225,904 & 117,960 & 80,690 & 221,280 \\
\hline $35-44$ & 67,725 & & 252,510 & 55,592 & & 266,015 & 104,216 & 11,618 & 212,879 & 74,565 & 32,786 & 222,171 \\
\hline $45-54$ & 64,003 & 9,098 & 311,614 & 50,930 & 8,005 & 325,781 & 94,676 & 17,188 & 272,852 & 74,112 & 24,612 & 285,158 \\
\hline $55-64$ & 44,796 & 15,009 & 304,405 & 28,086 & & 328,236 & 87,252 & 10,133 & 265,615 & 54,421 & 17,700 & 292,299 \\
\hline $\begin{array}{l}\text { Low } \\
\text { education }\end{array}$ & 52,502 & 13,115 & 638,183 & 46,027 & 10,605 & 646,825 & 119,820 & 13,358 & 568,714 & 108,049 & 37,304 & $55^{8,896}$ \\
\hline $\begin{array}{l}\text { Secondary } \\
\text { education }\end{array}$ & 105,375 & 14,827 & 399,313 & 80,246 & 15,770 & 423,926 & 169,248 & 22,993 & 327,080 & 127,811 & 67,229 & 324,410 \\
\hline $\begin{array}{l}\text { Higher } \\
\text { education }\end{array}$ & 134,469 & 29,919 & 106,183 & 110,695 & 33,988 & 125,890 & 159,127 & 31,950 & 79,029 & 85,198 & 49,870 & 134,934 \\
\hline
\end{tabular}

Source: INSTAT, 2017 
Table 4, shows the participation of respondents in cultural events by gender, age and level of education according to the types of cultural events.

With regards to gender, we can say that men have participated 1- 6 times and more than 6 times more than women in 2017, in almost all cultural events.

Men have participated more than 6 times and 1-6 times within the year, in these types of cultural events.

Compared to all types of cultural events, men have participated more in live sport events, more concretely $85 \%$ of the total number of surveyed men have participated in this type of event more than 6 times with a year. Also, $54 \%$ of the total number of surveyed men have participated in cultural site events $1-6$ times within a year.

Cultural events where male respondents have participated less during the year are: live performances and cinema where respectively $51 \%$ and $50 \%$ of the total number of respondents have never participated during the year in these events.

With regards to the women surveyed, the types of cultural events where women have participated the most within a year are: Live performances and cultural site. Where in both these types of cultural events, $53 \%$ of women surveyed have participated in the live performance event 1- 6 times a year, and in the cultural site event more than 6 times a year. The cultural event where the surveyed women have the lowest participation within the year is live sport events, where $63 \%$ of women have never participated in this event.

Regarding the age groups, we can say that the age group $25-34$ is the one that has participated more in cultural events compared to other age groups. The types of events where the age group 25-34 has participated the most are: Cinema, and live sport events, where $60 \%$ of the surveyed age group 25 34 has participated in the cinema event more than 6 times a year. Also, 52\% of the age group 25-34 has participated in the live sport events more than 6 times a year.

Regarding the level of education, we can say that the respondents with a high level of education, had a higher participation compared to all other respondents. The types of cultural events where the respondents with higher education participated the most are: Live performance and cinema, where $55 \%$ of respondents participated in the cinema event more than 6 times within a year, and $52 \%$ of respondents participated in the live performance event more than 6 times within a year.

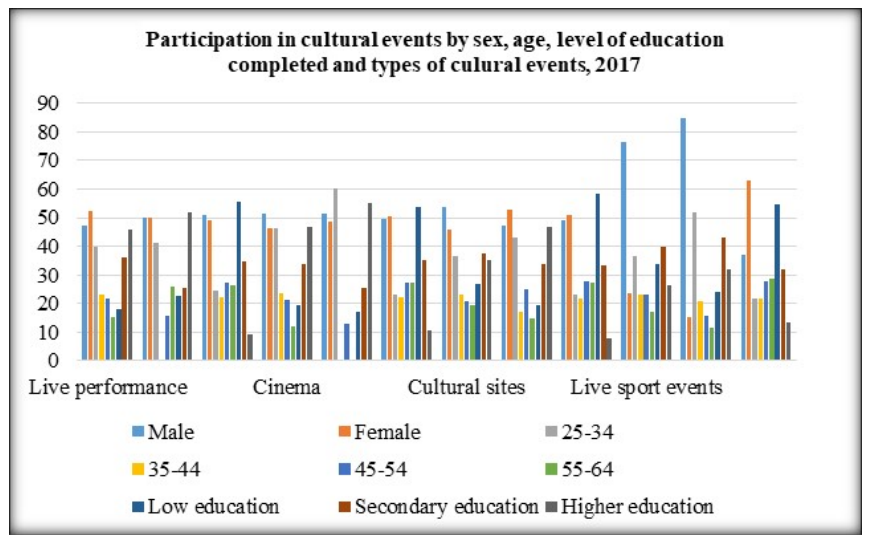

Chart 4. Participation in cultural events by gender, age groups, level of education attained regarding the types of cultural events, in 2017.

Source : Authors

Chart 4 shows the participation in cultural events, by gender, age groups and level of education attained regarding the types of cultural events, in 2017. 
With regards to gender, men have a higher participation in almost all cultural events compared to women. The type of cultural event where men have the highest number of participation are live sport events. $85 \%$ of men surveyed have participated in this type of event more than 6 times a year. The types of events where women have participated the most are: Live performance and cultural sites, where $53 \%$ of the total number of women surveyed have participated in these two types of events respectively 1- 6 times and more than 6 times within a year.

Regarding age groups, the age group 25-34 has participated more in all types of cultural events compared to all other age groups. The types of cultural events where this age group has participated the most are cinema events. $60 \%$ of the total number of surveyed age group $25-34$, has participated in the cinema event more than 6 times within a year.

Regarding the level of education, respondents with higher level of education have participated more in cultural events compared to all other levels of education. The types of cultural events where respondents with higher education have participated the most are: in cinemas and live performances, where $55 \%$ of the respondents have participated in the cinema event more than 6 times a year.

Whereas, $52 \%$ of respondents with higher education have participated in live performance events more than 6 times a year.

\section{Conclusions and Recommendations}

Based on the results of the analysis, we conclude that in terms of participation in formal, non-formal and informal education by gender, age and educational level, the level of participation has been higher in informal education compared to formal and non-formal education. With regards to gender, men have a higher participation in informal education compared to women. Concerning age groups, the age group 25-34 is the one that has participated the most in informal education. With regards to the level of education, respondents who have a level of higher education have participated more in informal education compared to other levels of education.

Based on the results of the analysis regarding the methods of informal learning by gender, age groups, and level of education we can say that: With regards to gender, the informal learning methods where men and women are more focused are as follows: The method of education from family and friends, museums and the method of informal learning from computer, libraries and materials.

Regarding age groups, the age group 25-34 is more focused on almost all informal learning methods compared to all other age groups under study.

In terms of education level, respondents with higher level of education are more focused on almost all of the informal learning methods, compared to respondents with other levels of education. Regarding the analysis on the knowledge for the number of foreign languages spoken by respondents by gender, age and level of education. We came to the conclusion that women speak more foreign languages than men. Regarding age groups, the age group 25-34 speaks more foreign languages compared to other age groups. Based on the level of education, respondents with a higher level of education speak more foreign languages compared to other levels of education.

Based on the participation of respondents in different types of cultural events by gender, age groups, and level of education, we can say that:

Based on gender, men have participated in different types of cultural events more than 6 times a year compared to women. The types of events where men have participated more than 6 times a year are live sport events. Regarding age groups, the age group 25-34 has participated more in different types of cultural events compared to all other age groups.

The types of cultural events where the age group 25-34 has participated the most by more than 6 times a year are cinemas and live sport events. Regarding the level of education, respondents with higher level of education have participated more in different cultural events compared to all other levels of education. The types of events attended by respondents with higher education, by more than 6 times a year are cinemas and live performances.

Regarding the conclusions drawn from the analysis, we highlight many significant problems 
regarding the quality of education in Albania. We also came to the conclusion that we definitely need support and important government policies in order to increase the quality of education in Albania for a better economic growth in the future. We also came to the conclusion that the main problem regarding education in Albania is that there are more advantages in terms of participation of respondents in informal education compared to the participation of the latter in formal and non-formal education. Formal education is very important for the individual as it contributes to the development of socio-emotional skills such as attention, motivation, self-confidence and physical and mental health, which are all determinants of the ability to move from one socio-economic stratum to another. It is therefore important for the government to undertake steps through government policies in order to increase youth participation in formal and non-formal education. It needs to create equal opportunities for the education of youth and establish a balance between urban and rural areas (Çela, R; Denaj, E; Geiger, A; Hantke, F; Hartig, S; Heusinger, W; Kasten, A; Limaj, S; Reidenbach, R, 2013).

Another recommendation would be for the government to prioritize investments in education, by providing youth favorable conditions in the formal education. These policies include investments in infrastructure, schools, universities, dormitories, etc...

Another government policy is the issue of student funding, which as we have mentioned is very important, and therefore the government must make sure that the issue of student funding is not just a matter that concerns students and parents. An important government policy in this regard is to provide favorable tuition fees for higher education and financial support for those impoverished families who are unable to study due to high tuition fees (Çela, R; Denaj, E; Geiger, A; Hantke, F; Hartig, S; Heusinger, W; Kasten, A; Limaj, S; Reidenbach, R, 2013). The improvement of the education quality affects directly the economic growth, as all sectors with perspective must have a qualified workforce. Public and private higher education institutions should be regularly monitored, in terms of meeting and maintaining quality standards by regularly undergoing the accreditation process (Çela, R; Denaj, E; Geiger, A; Hantke, F; Hartig, S; Heusinger, W; Kasten, A; Limaj, S; Reidenbach, R, 2013) . The government needs to invest more in the improvement of education quality by investing in information points for pupils and students that serve as support tools for youth regarding their career planning and counseling. Another important government policy which would help in the improvement of education quality is an investment made for the provision of integrated internships for university study programs and for the provision of practice-oriented curricula (Çela, R; Denaj, E; Geiger, A; Hantke, F; Hartig, S; Heusinger, W; Kasten, A; Limaj, S; Reidenbach, R, 2013).

A major issue for youth in Albania is unemployment, because most of the post graduated students struggle to find a job, and to be more precise they struggle to find a job which is related to their field of studies. Therefore, the role of the government in this regard should be comprehensive and very important. The main problem that they face is the lack of experience and trainings. In this case the government should adopt active employment policies, by cooperating with businesses of various private sectors, by providing ongoing information programs for young people about employment offers and offers for professional qualifications, as well as by offering multi functional centers which include various levels of professional qualifications (Çela, R; Denaj, E; Geiger, A; Hantke, F; Hartig, S; Heusinger, W; Kasten, A; Limaj, S; Reidenbach, R, 2013). Another important issue related to unemployment is that of the inequality that young people face regarding unemployment. Employment opportunities are not equal for graduates and the evaluation criteria vary from one job to another and are not equal. This inequality regarding the evaluation criteria for employment is present in almost all countries with developing economies, which is quite different from the countries with developed economies. The government should definitely intervene through effective government policies to improve the effect of inequality on employment. This can be achieved by building partnerships with foreign experts from developed countries in order to exchange their good practices and specific experiences related to this issue, because a qualitative and well-qualified workforce would be an important impetus for any institution or business and that would also help the economic growth of the country. Other government policies that can be undertaken in order to improve the quality of education are: The improvement of quality and equality in education. The analysis clearly showed that 
in Albania, education has inequality and gender differences, especially in terms of participation in formal, non-formal and informal education, and in terms of participation in cultural events within a year, where men had a higher number of participation compared to women. In addition to gender inequalities, in terms of education in Albania there are significant urban-rural and socio-economic inequalities (School of Education, 2019). These issues cannot be solved within a short period; therefore, they require effective long-term policies.

\section{References}

Berger, N., \& Fisher, P. (2013). A Well-Educated Workforce Is Key to State Prosperity. Economic Policy Institute. Washington: EARN, Economic Analysis and Research Network [Online] Available: https://files.epi.org/2013/A well-educated workforce is key to state prosperity.pdf ( August, 2013).

Çela, R; Denaj, E; Geiger, A; Hantke, F; Hartig, S; Heusinger, W; Kasten, A; Limaj, S; Reidenbach, R. (2013). Economic development - Professional education - Welfare for Albania. National Conference (pp. 4-7). Tiranë: Foundation "Friedrich Ebert" [Online] Available: https://library.fes.de/pdf-files/bueros/albanien/10894.pdf (October, 2013).

Eaton, S. E. (2010, December). Formal, non-formal and informal learning. ResearchGate, 1-5.

Hanushek, E. A., \& Wößmann , L. (2007). The Role of Education Quality in Economic Growth. World Bank Policy Research Working Papers. World Bank Policy Research Working Paper 4122, [Online] Available: file:///C:/Users/User/Downloads/The_Role_of_education_quality_for_economic_growth.pdf

(February ,2007).

INSTAT. (2017). (INSTAT) Institute of Statistics, Albania, The Labor Market and Education. Retrieved from Instad.gov.al, [Online] Available: http://www.instat.gov.al/al/temat/tregu-i-punës-dhe-arsimi/të-mësuaritgjatë-gjithë-jetës/\#tab2 (2017).

School of Education, o. p. (2019). [Online] Available : https://soeonline.american.edu/blog/5-ways-policy-makerscan-improve-the-quality-of-education (April, 2019). 